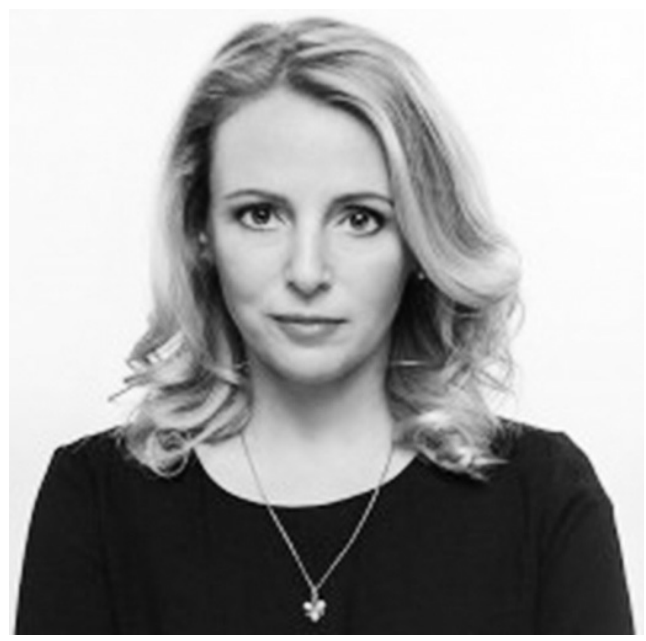

UDC: 330.341.1:351

DOI: https://doi.org/10.32689/26172224-2019-4(19)-320-331

\section{Юзъкова Олена Іванівна,}

аспірантка, Таврійський нащіональний університет за спеціальністю "Державне управління”, 02068, м. Київ, вул. Драгоманова, 31б, тел.: +38 (099) 0794680 , e-mail: e.yuzkova@gmail.com

ORCID: 0000-0002-0344-9693

\section{Юзъкова Елена Ивановна,} аспирантка, Таврийский национальный университет по специальности "Государственное управление”, 02068, г. Киев, ул. Драгоманова, 316, тел.: +38 (099) 079 46 80, e-mail: e.yuzkova@gmail.com

ORCID: 0000-0002-0344-9693

Yuzkova Olena Ivaniona,

PhD Candidate, Tavriyskiy National University, specialization "Public Management", 02068, Kyiv, Str. Dragomanova, 31B, tel.: +38 (099) 07946 80, e-mail: e.yuzkova@gmail.com

ORCID: 0000-0002-0344-9693

\title{
ІННОВАЦІЙНЕ ЛІДЕРСТВО ЯК ФОРМА ПРОФЕСІЙНОЇ ЕВОЛЮЦІї В ДЕРЖАВНОМУ УПРАВЛІННІ
}

Анотація. Проблемні питання впровадження механізмів інноваційного лідерства в діяльність органів державної влади в Україні в умовах суспільних змін привертають все більше уваги дослідників різних наукових напрямів. Цей процес має кілька базисних детермінантів, які представлені за результатами дослідження поведінки інноваційного лідера в організації на засадах організаційного досвіду. Надано порівняльний аналіз бачення інноваційного лідера представниками органів державної влади та представниками бізнесу з точки зору особистісних характеристик та поведінкової моделі всередині організації з метою виявлення закономірностей до формування інноваційного лідерства як форми професійної еволюції у сфері державного управління та в бізнес-середовищі. Досліджено понятійний та методичний аспект інноваційного лідерства на основі виявлення когніцій щодо бачення інноваційного лідерства в управлінні організаціями, зокрема в державному управлінні. Дослідження орієнтоване на поглиблення розуміння такого явища як інноваційне лідерство, тобто детальним вивченням і розумінням 
інноваційного лідерства в його цілісності і безпосередньому взаємозв’язку з іншими явищами.

Зазначено, що бізнес завжди першим впроваджує нові ідеї та концепції, а громадський сектор та державні організації переймають досвід. Наразі, у зв’язку з вимогами зовнішнього середовища, бізнес шукає нові відповіді на старі питання: що таке лідерство? Яка організація буде ефективною? I зараз ми бачимо, як компанії впроваджують нову культуру, що сприяє інноваціям, творчості, дає можливість експериментувати, і діляться напрацюваннями, стають прикладом для інших. Чи не найголовніший виклик сьогодення - створювати культуру відповідальності, у якій рішення та пропозиції надходять не від авторитетної особи, представника влади, а від людей на усіх рівнях.

Ключові слова: інноваційне лідерство, інноваційне лідерство в державному управлінні, державне управління, розвиток інноваційного лідерства.

\section{ИННОВАЦИОННОЕ ЛИДЕРСТВО КАК ФОРМА ПРОФЕССИОНАЛЬНОЙ ЭВОЛЮЦИИ В ГОСУДАРСТВЕННОМ УПРАВЛЕНИИ}

Аннотация. Проблемные вопросы внедрения механизмов инновационного лидерства в деятельность органов государственной власти в Украине в условиях социальных изменений привлекают все больше внимания исследователей различных научных направлений. Этот процесс имеет несколько базисных детерминантов, которые представлены в сравнении по результатам исследования поведения инновационного лидера в организации на основе организационного опыта. Представлен сравнительный анализ видения инновационного лидера представителями органов государственной власти и представителями бизнеса с точки зрения личностных характеристик и поведенческой модели внутри организации с целью выявления закономерностей к формированию инновационного лидерства как формы профессиональной эволюции в сфере государственного управления и в бизнес-среде. Исследованы понятийный и методический аспекты инновационного лидерства на основе выявления когниций касательно видения инновационного лидерства в управлении организациями, в частности в государственном управлении. Исследование ориентировано на глубину понимания такого явления, как инновационное лидерство, то есть детальным глубинным изучением и пониманием инновационного лидерства в его целостности и непосредственной взаимосвязи с другими явлениями.

Отмечено, что бизнес всегда первым внедряет новые идеи и концепции, а общественный сектор и государственные организации перенимают опыт. Сейчас в связи с требованиями внешней среды, бизнес ищет новые ответы на старые вопросы: что такое лидерство? Какая организация будет эффективной? И сейчас мы видим, как компании внедряют новую культуру, которая способствует инновациям, творчеству, позволяет экспериментировать, и делятся наработками, становятся примером для других. Не самый ли главный вызов нашего времени - создавать культуру ответственности, в которой ре- 
шения и предложения поступают не от авторитетного лица, представителя власти, а от людей на всех уровнях.

Ключевые слова: инновационное лидерство, инновационное лидерство в государственном управлении, государственное управление, развитие инновационного лидерства.

\title{
INNOVATION LEADERSHIP AS A FORM OF PROFESSIONAL EVOLUTION IN PUBLIC ADMINISTRATION
}

\begin{abstract}
Problematic issues of innovation leadership mechanisms implementationingovernmentbodiesin Ukraineduringsocialchangesattractmore and more attention of researchers from different scientific fields. This process has several basic determinations which are represented in comparison built upon research results of innovative leader behaviour in organization based on organizational experience. The article provides comparative analysis of vision of an innovative leader made by representatives of public authorities as well as business representativesin relation with personal characteristicsand behaviour modelinside the organization in order to find out common factors as for innovation leadership forming as a professional evolution method in public administration and business environment. The article presents the research of conceptual construct as well as methodological aspects of innovation leadership based on cognitions discovery as for innovation leadership vision in organizational management, in particular in public management. The research is focused on depth of understanding such phenomenon as innovation leadership (not width as in quantitative/mass research) - i.e. detailed deep research and understanding of innovation leadership in its integrity and direct connection with other phenomena.

It is noted that that the business is always the first to introduce new ideas and concepts, and the public sector and government organizations take on the experience. Now, due to the requirements of the environment, the business is looking for new answers to the old questions: what is leadership? Which organization will be effective? And now we see how the companies introduce a new culture that promotes innovation, creativity, allows you to experiment, and share the groundwork, and become an example for the others. The most important challenge today is to create a culture of responsibility in which the decisions and proposals come not from an authoritative person, a representative of the power, but from people at all the levels.
\end{abstract}

Keywords: innovation leadership, innovation leadership in public administration, public management, innovation leadership development.

Постановка проблеми. Проблемність ситуації полягає в тому, що, незважаючи на те, що теоретично інтереси суспільства, організації і осо- бистості у забезпеченні сприятливих умов для інноваційного лідерства збігаються, на практиці спостерігається очевидні протиріччя між їх за- 
питами по відношенню до лідерства і можливостями організації в даних соціально-економічних i управлінських умовах реалізувати потенціал інноваційного лідерства своїх співробітників. В більшості організацій ця різниця досягає критичних значень і породжує серйозні передумови соціально-психологічних i економічних проблем. Вона буває як зі знаком “плюс”, так і зі знаком “мінус", коли потенціал управлінця в умовах, що склалися, не може бути в принципі затребуваний. Протягом кількох останніх десятиліть уявлення про лідерство суттєво змінилися, як і очікування від самого лідера. З’явилися фактори, що значно ускладнили наше розуміння світу та його правил, а саме:

- розвиток технологій;

- розмивання кордонів, розвиток глобальної економіки;

- міграція населення;

- боротьба за ресурси.

Таким чином з'явилася необхідність в появі на державному рівні не просто лідерів, а саме інноваційних лідерів.

Сучасний інноваційний лідер це агент змін на локальному та глобальному рівнях. Це не означає контроль процесів від початку до кінця, інколи достатньо показати шлях, залучити, а інші підхоплять та масштабують результати. Тому кожен може бути лідером - агентом змін - на своєму рівні.

Аналіз останніх досліджень i публікацій. Серед науковців поки що відсутня єдина думка щодо визначення механізмів сталого розвитку лідерства та сприяння вдосконаленню результативності та ефективності зазначених механізмів. Вивченнямпитаньлідерствавсистемі державного управління займаються Є. Абашкіна, Б. Кухта, М. Логунова, В. Міщишин, Л. Пашко та ін. Значний внесок в дослідження ефективності державного управління зробили В. Авер'янов, В. Бакуменко, А. Мельник та ін.

Метою статті є дослідження понятійного та методичного аспектів інноваційного лідерства як форми професійної еволюції на основі виявлення когніцій щодо бачення інноваційного лідерства в управлінні організаціями, зокрема в державному управлінні.

Виклад основного матеріалу. $\mathrm{Pi}$ вень інституційних змін у будь-якій сфері державного управління визначається ефективністю реалізації системи управління відповідними державними інститутами. Нині на перший план виходить необхідність вирішення проблем удосконалення системи управління в державних інститутах у напрямі забезпечення результативності та ефективності виконання відповідних функцій і надання послуг [1].

Розглянемо результати дослідження деяких параметрів інноваційного лідерства, індивідуальних і соціальних, що ототожнюється сьогодні з управлінськими. Перші пов’язані 3 актуалізацією потреби людини в забезпеченні власної безпеки і благополуччя в умовах мінливого та такого, що швидко розвивається, середовища життєдіяльності; другі - зі зростанням значення у всіх громадських, в тому числі економічних процесах так званого людського фактора, в основі якого лежать ін- 
дивідуальні лідерські потенції, мобілізовані і організовані в інтересах системи і окремої особистості [2]. Показником успіху інноваційного лідера є не те, наскільки він впливова та важлива людина, не рівень покірності та страху його послідовників. Такий лідер вчить людей відповідальності на своєму рівні: добре виконувати свою роботу, будувати стосунки, фокусуватися на потребах клієнта, вивчати та застосовувати нові технології. Окрім цього, справжній агент змін має бачити океан, а не хвилі у ньому, він має мислити більш системно та широко. Щоб зорієнтуватись у викликах сьогодення, варто розуміти глобальні причини, тренди, системну динаміку, розуміти вплив своїх дій на загальну картину. Потрібно відійти від режиму реагування, припинити “гасити пожежі”, підняти голову, більше аналізувати та спостерігати.

У 2010 р. вперше в України були проведені широкомасштабні дослідження, які реалізуються з року в рік (анкетування, фокус-групи та напівструктуровані інтерв’ю) українських посадовців, для врахування їхнього бачення при визначенні ключових груп професійних компетенцій лідерства, потреб у навчанні та розвитку. Вивчення потреб відбувалося 3 використанням методики оцінювання "360 градусів”. Сутність методу “360 градусів” полягає в тому, що співробітника оцінюють кілька осіб 3 його робочого оточення: керівник, колега, наставник, колега по проекту і т. п. Зазвичай кількість оцінювачів становить не менше 4-х осіб, що дає змогу уникнути суб'єктивного фактора в оцінці співробітника однією людиною. При використанні цього методу оцінюються професійні та особистісні компетенції, необхідні для ефективної роботи співробітника на займаній посаді. Подібний метод оцінювання дозволяє не тільки оцінити співробітників на відповідність вимогам організації, але i визначити їхні слабкі сторони. Дана інформація є відправною точкою для розробки як загальної стратегї̈ навчання i розвитку в організації, так і індивідуальних планів розвитку для кожного окремого співробітника. Часто метод 360 градусів, крім кругової оцінки ділового оточення, включає також самооцінку, що дозволяє оцінити ступінь відповідності думки співробітника про себе з думкою інших оцінювачів і, тим самим, дати більш повний i корисний зворотний зв'язок [3].

Сьогодні в Україні реалізується Програма розвитку лідерства 2014, яка закладає підвалини для вдосконалення управління людськими ресурсами, професіоналізації державної служби, сталого розвитку лідерства та сприяння вдосконаленню ефективності діяльності державного управління в цілому [3]. Важливо, що ця програма була розроблена на основі вивчення потреб у навчанні керівників на державній службі в Україні відповідно до проекту основних груп компетенцій лідерства.

Метою представленого дослідження було порівняти індивідуальні потенції інноваційних лідерів, мобілізовані і організовані в інтересах системи - державного управління та бізнес-середовища та зрозуміти, які відповіді представники органів державної влади та представники бізне- 
су знаходять на питання “Що таке інноваційне лідерство та його ефективні механізми в управлінні процесами в умовах суспільних змін?”

Дослідження орієнтоване на глибину розуміння такого явища, як інноваційне лідерство (ІЛ), тобто детальним, глибинним вивченням i розумінням інноваційного лідерства в його цілісності і безпосередньому взаємозв’язку з іншими явищами, наприклад:

- IЛ в державному управлінні / ІЛ в бізнес-середовищі;

- відносини (взаємодія);

- мотивація до розвитку своїх компетенцій та лідерських якостей.

Також було досліджено деякі параметри інноваційного лідерства, а саме: ідентичність інноваційного лідера (ідентифікація інноваційного лідера), інноваційне лідерство в системі організації (інноваційне лідерство в системі - бізнес та органи державної виконавчої влади - на основі досвіду респондентів); відносини (взаємодія) в колективі / в організації (інноваційне лідерство крізь призму відносин в колективі/організаціï); потреба у навчанні та розвитку лідерських якостей (інноваційне лідерство крізь призму мотивації та розвитку компетенцій “я-досвід”).

Дослідження здійснювалося в період 34 лютого 2019 р. по 17 березня 2019 року. В рамках дослідження проведено 4 фокус-групи - 2 групи представників органів державної виконавчої влади та 2 групи представників бізнесу.

Цільовими містами було обрано м. Київ та м. Маріуполь.

Було опитано 48 респондентів, 3 яких 24 (12 чоловіків та 12 жінок, ві- ком від 23 до 57 років, з досвідом роботи в органах державної виконавчої влади від 2 до 15 років) - представляють органи державної виконавчої влади, а 24 (16 чоловіків та 8 жінок, віком від 32 до 45 років, з управлінським досвідом в бізнесі від 5 до 14 років) - представники різних галузей бізнесу.

Достовірність дослідження забезпечується типовістю учасників.

Дослідження відбувалося за двома етапами.

1-й етап. Ідентифікація особистості інноваційного лідера через складання його портрета через особисті риси та поведінку.

Під час дослідження використовувалися "якісні методології соціологічного дослідження”. Основна перевага використання такого підходу полягає у виявленні нових смислів, які впливають на поведінку. Тому було обрано метод фокус-груп з тим, щоб на етапі теоретичного обгрунтування деяких положень в рамках дисертаційного дослідження автора уточнити дані щодо інтерпретації поняття інноваційного лідерства в двох різних сферах управління державному управлінні та бізнес-середовищі.

Оцінка зовнішніх особистих рис i поведінки сприяла одержанню наступних результатів:

Усі групи респондентів зазначили важливість приємної зовнішності, привабливості інноваційного лідера, значущість того, щоб ця людина сприймалась як сильна особистість, яка творчо підходить до завдань та процесів, в яких знаходиться.

Але представники органів державної виконавчої влади наголошу- 
вали на необхідності широкого світогляду, прогресивних поглядів та спрямованість на системний саморозвиток, у той час як представники бізнесу важливим вбачали сформовану систему цінностей, внутрішній етичний кодекс та високий емоційний інтелект (табл. 1).

Щодо поведінкових характеристик, то важливим для представників всіх категорій здалося вміння ризикуючи втілювати всіх нові ідеї. Для представників органів державної виконавчої влади необхідною $є$ характеристика "брати відповідаль- ність на себе”, в той час як представники бізнесу вважливим важають створення цінності та інший погляд на світ (табл. 2).

Наразі в державному управлінні в Україні поширена практика трансферу інноваційних лідерів з бізнесу в державне управління. Тому 2-й етап дослідження був пов'язаний з дослідженням компетенцій поза системою (трансфер компетенцій, при переміщенні лідерів з бізнесу в органи державної виконавчої влади). Учасники побачили певні чинники, які можуть призвести як до успіху,

Портрет особистих рис інноваційного лідера

Таблиця 1

\begin{tabular}{|l|l|}
\multicolumn{1}{|c|}{ Представники органів державної } & \multicolumn{1}{|c|}{ Представники бізнесу } \\
\hline Приємний на зовнішність & Приємна зовнішність \\
Сміливий & Сильний \\
Наполегливий & Відкритий \\
Сильний & Творчий \\
Мужній & Цілеспрямований \\
Харизматичний & Схильність до ризику \\
Ерудований & \\
Мудрий & \\
Освічений & Сформована система цінностей \\
Має широкий світогляд & Внутрішній етичний кодекс \\
Має широкі прогресивні погляди & Має мрію \\
Спрямований на систематичний саморозвиток & “Незручний для команди" \\
Організований & Поєднує “молодість душі" \\
Має чітку місію та бачення (бачить шлях) & з професійним досвідом \\
Цілеспрямований & Професіонал \\
Конкретний & Постійно генерує нові ідеї \\
Відповідальний & Вміє адаптувати те, що добре \\
Мислить нестандартно & працює \\
Стратег & Вміє працювати з невдачей \\
Креативний & Вміє тримати удар \\
Інший за поглядами & Вміє слухати \\
Діє нестандартно & \\
Нестандартні/нешаблонні підходи/інструменти & \\
Не зупиняється на досягнутому & \\
Прагне змін і втілює їх & Знання психології \\
\hline
\end{tabular}


так і до поразки інноваційного лідера з бізнесу при переході його в державне управління. Так, представники органів державної виконавчої влади зазначили, що ресурси в бізнесі та на держслужбі використовуються під різні задачі. В бізнесі - отримати результат, в держслужбі - переобратися. Відповідно, лідерам, які звикли до спрямованості на результат може бути складно переорієнтуватися на більш процесну роботу. Представники органів державної виконавчої влади також зазначили, що в бізне- сі лідер має більше важелів впливу, аніж в державному управлінні, відповідно, йому доведеться навчитися досягати цілей значно меншою кількістю інструментів.

Представники бізнесу зазначили, що оскільки в бізнесі більше свободи та грошей, може бути не зрозуміла мотивація переходу лідера 3 бізнесу в органи державної виконавчої влади. Також ними був відмічений ризик відсутності “драйву”, який, власне, і є основою створення інновацій, через велику бюрократизацію

Таблиця 2

Портрет поведінкових рис інноваційного лідера

\begin{tabular}{|l|l|}
\hline \multicolumn{1}{|c|}{$\begin{array}{l}\text { Представники органів державної } \\
\text { виконавчої влади }\end{array}$} & \multicolumn{1}{|c|}{ Представники бізнесу } \\
\hline $\begin{array}{l}\text { Веде за собою } \\
\text { Бере відповідальність } \\
\text { Привносить нові ідеї }\end{array}$ & $\begin{array}{l}\text { Розповідає про свої невдачі } \\
\text { Намагається щось покращити та змінити } \\
\text { Не боїться ризикувати }\end{array}$ \\
Надихає & Створює цінність \\
Ризикує & Постійно саморозвивається та вчиться \\
Формує довіру & $\begin{array}{l}\text { Працює інструментами, які ніхто не вико- } \\
\text { ристовував раніше } \\
\text { Реалізує на практиці } \\
\text { Приймає рішення }\end{array}$ \\
\hline
\end{tabular}

Таблиця 3

Характеристики, які сприяють успіху лідерів з бізнесу в державному управлінні

\begin{tabular}{|c|c|}
\hline $\begin{array}{c}\text { Представники органів державної } \\
\text { виконавчої влади }\end{array}$ & Представники бізнесу \\
\hline $\begin{array}{l}\text { Свіжий погляд } \\
\text { Орієнтація на результат } \\
\text { Орієнтація на клієнта } \\
\text { Орієнтація на ефективність } \\
\text { Досвід управління інноваціями } \\
\text { Чітке бачення цілей та завдань } \\
\text { Оцінка ризиків та вміння прогнозувати }\end{array}$ & $\begin{array}{l}\text { Інтелект } \\
\text { Дипломатичність } \\
\text { Комунікації } \\
\text { Орієнтація на результат } \\
\text { Орієнтація на клієнта } \\
\text { Вміння “продавати” } \\
\text { Вміння приймати виклики } \\
\text { Вміння створювати команди } \\
\text { Вміння управляти людьми } \\
\text { Вміння відрізняти відоме для ринку } \\
\text { від невідомого } \\
\text { Вміння оцінювати ризики }\end{array}$ \\
\hline
\end{tabular}




\section{Характеристики, які заважають успіху лідерів}

з бізнесу в державному управлінні

\begin{tabular}{|c|c|}
\hline $\begin{array}{c}\text { Представники органів } \\
\text { державної виконавчої } \\
\text { влади }\end{array}$ & Представники бізнесу \\
\hline $\begin{array}{l}\text { - Неможливість поруши- } \\
\text { ти закон } \\
\text { - Важлива увага до соці- } \\
\text { ального аспекту } \\
\text { - Не все можна оціни- } \\
\text { ти через економічний } \\
\text { ефект }\end{array}$ & $\begin{array}{l}\text { - Інший (більш повільний) темп роботи органів державної } \\
\text { виконавчої влади } \\
\text { - Процедури в бізнесі простіше за процедури на держав- } \\
\text { ній службі } \\
\text { - Державна служба має більшу кількість операційних за- } \\
\text { вдань ніж бізнес } \\
\text { - В системі держслужби людина не може працювати са- } \\
\text { мостійно } \\
\text { - Всередині структури органів державної виконавчої вла- } \\
\text { ди важко створити команду } \\
\text { - Робота органів державної виконавчої влади залежить } \\
\text { від політичних циклів }\end{array}$ \\
\hline
\end{tabular}

на державній службі. На думку лідерів з бізнесу, представники бізнесу мають займати в державному управлінні більш високі посади, які надають більшу свободу дій та сприяють розвитку інноваційного лідерства.

I навпаки, серед тих характеристик, які можуть заважати цьому успіху були названі:

Важливо зазначити, що як представники органів державної виконавчої влади, так і представники бізнесу визначили наявність місії в своїх організаціях, але при цьому ключові цінності цих категорій дуже різняться.

Ключові цінності, що панують на держслужбі, наразі - робити більше 3 меншими витратами; створювати сприятливу робочу атмосферу та ставитися один до одного з повагою, шукати нові підходи до роботи. Представники бізнесу основними цінностями визначили чесність, практичний підхід, прагнення росту та навчанню.

Відомо, що зворотньою стороною особистого інноваційного лідерства має бути інноваційна корпоративна культура. Тут також спостерігаємо різницю: в органах державної виконавчої влади корпоративну культуру характеризують як авторитарно-демократичну, а в бізнесі - як демократичну.

Серед компетенцій інноваційного лідера називають у тому числі:

- управління змінами;

- управління людьми;

- орієнтація на результат;

- бізнес спроможності/хватка.

Ранжування компетенцій виявило найбільшу схожість між представниками обох груп. Як бачимо, представники органів державної виконавчої влади і бізнесу визначили найважливішими компетенціями управління змінами і управління людьми (табл. 5).

Лідерство - феномен, який потребує постійної роботи з власною особистістю. Отже, наступним питанням ми спробували визначити, що саме може стати чинниками мотивації для подальшого розвитку 
інноваційного лідерства. Як бачимо, представники органів державної виконавчої влади одноголосно назвали єдиний мотиваційний чинник, в той час як представники бізнесу мають їх цілу низку (табл. 6).

Оскільки ми передбачаємо необхідність впровадження механізмів розвитку інноваційного лідерства в державне управління, то було б дуже важливо дізнатись, які саме теми вважають необхідними для цього розвитку представники обох категорій (табл. 7).

Висновки. Проведене дослідження дозволило одержати наступні результати:

1. Інноваціний лідер $е$ завжди креативним. Він харизматичний. В нього високий емоційний інтелект. Він не боїться щось робити по-новому. Його завжди поважають. Він вимогливий.
2. Необхідність розвитку інноваційного лідерства була визнана однією 3 ключових компетенцій для керівників як в органах державної виконавчої влади, так і в бізнесі.

3. Трансфер інноваційних лідерів з бізнесу до органів вищої виконавчої влади може бути дуже успішним за умови дотримання певних вимог.

4. Учасникам фокус-груп було найважче (складніше) пояснити моменти, пов'язані:

• з різницею в поняттях “лідер” та “інноваційний лідер”, часто ці поняття ототожнювались, оскільки саме поняття “лідер” для багатьох учасників вже включало поняття "інноваційність";

- мотивацією переходу лідерів 3 бізнесу в органи державної виконавчої влади - вона не завжди зрозуміла представникам обох груп.

Таблиця 5

Бачення необхідності компетенцій інноваційного лідерства

\begin{tabular}{|c|c|}
\hline $\begin{array}{c}\text { Представники органів державної } \\
\text { виконавчої влади }\end{array}$ & Представники бізнесу \\
\hline $\begin{array}{l}\text { - Перша позиція в ранжуванні - найваж- } \\
\text { ливіша - управління змінами } \\
\text { - Друга позиція - управління людьми } \\
\text { - Третя позиція - бізнес- здібності/хватка } \\
\text { - Четверта позиція - орієнтація на ре- } \\
\text { зультат }\end{array}$ & $\begin{array}{l}\text { - Перша позиція в ранжуванні - найваж- } \\
\text { ливіша - управління змінами } \\
\text { - Друга позиція - управління людьми } \\
\text { - Третя позиція - орієнтація на результат } \\
\text { - Четверта позиція - бізнес-здібності/ } \\
\text { хватка }\end{array}$ \\
\hline
\end{tabular}

Таблиця 6

Чинники мотивації для подальшого розвитку інноваційного лідерства

\begin{tabular}{|c|c|}
\hline $\begin{array}{c}\text { Представники органів } \\
\text { державної виконавчої влади }\end{array}$ & Представники бізнесу \\
\hline $\begin{array}{l}\text { - Бажання змінити існуючу ситу- } \\
\text { ацію, але не вистачає знань }\end{array}$ & $\begin{array}{l}\text { 1. Розуміння того, що всі зміни починаються з себе. } \\
\text { 2. Подальші: } \\
\text { • готовність ділитися власним досвідом } \\
\text { • бажання змінити ситуацію як } \\
\text { - бажання рухатися далі } \\
\text { - наявність необхідних якостей для такого навчання }\end{array}$ \\
\hline
\end{tabular}


Пріоритети розвитку інноваційного лідерства в державному управлінні

\begin{tabular}{|c|c|}
\hline $\begin{array}{c}\text { Представники органів державної } \\
\text { виконавчої влади }\end{array}$ & Представники бізнесу \\
\hline $\begin{array}{l}\text { - Стратегічне бачення, стратегічне } \\
\text { управління } \\
\text { • Використання сучасних технологій } \\
\text { управління людьми та процесами } \\
\text { - Навички креативного мислення }\end{array}$ & $\begin{array}{l}\text { • Управління змінами } \\
\text { • Інновації та інноваційність як феномен } \\
\text { та її політичні виявлення } \\
\text { • Психологія команди }\end{array}$ \\
\hline
\end{tabular}

Більшість учасників дослідження розуміють, що розвиток інноваційного лідерства є необхідною складовою для подальшого кар'єрного росту як в органах вищої виконавчої влади, так і в бізнес-середовищі.

Практично всі також можуть назвати особистісні риси та поведінкові моделі, які сприяють успіху в розвитку інноваційного лідерства.

Більш складним виявилося питання, чим саме інноваційний лідер відрізняється від лідера.

Певна частина респондентів вагалися між варіантами, що інноваційний лідер - це лідер, який постійно генерує нові ідеї та нові шляхи вирішення складних ситуацій, а інша частина вважала інноваційним лідерством успішне втілення цих рішень та ідей на практиці як власне самим лідером, так і вмінням інноваційного лідера надихнути на це команду.

Незважаючи на те, що всі учасники дискусій погоджувалися, що переведення лідерів з бізнесу в органи вищої виконавчої влади може бути дуже успішним, певна частина з них висловлювали сумніви щодо їх можливості працювати в органах вищої виконавчої влади тривалий час у зв'язку з різницею в системі цінностей та особливостей організаційної культури в бізнесі та на держслужбі.
Такі респонденти зазначали, що підвищена бюрократизація в органах вищої виконавчої влади не сприяе гнучкості та орієнтації на результат, які є основними вимогами для лідерів в бізнес-середовищі. Але частина опитаних не виключають, що лідери з бізнесу можуть бути успішними за умов роботи на більш високих посадах, де вони матимуть більше необхідної для них свободи та повноважень та за умов розуміння ними політичних циклів в країні.

Проведене дослідження дає змогу виокремити особливості інноваційного лідерства як форми професійної еволюції в державному управлінні через визначення та аналіз поведінкових та особистісних складових, а також встановити закономірності до формування інноваційного лідерства у сфері державного управління та у бізнес-середовищі.

\section{СПИСОК ВИКОРИСТАНИХ ДЖЕРЕЛ}

1. Ткачова О. Ефективність державного управління: поняття та підходи до оцінювання / О. Ткачова // Вісн. Нац. акад. держ. упр. при Президентові України. 2013. № 2. С. 30-37.

2. Поспєлова Т. В. Механізми державного управління людським розвитком в Україні: монографія / Т. В. По- 
спєлова. Донецьк: Норд-Прес, 2011. $350 \mathrm{c}$.

3. Розвиток лідерства / Л. Бізо, І. Ібрагімова, О. Кікоть, С. Барань, Т. Федорів ; за заг. ред. І. Ібрагімової. К. : Проект "Реформа управління персоналом на державній службі в Україні”, 2012. 400 c.

\section{REFERENCES}

1. Tkachova O. (2013). Efektyvnist derzhavnoho upravlinnia: poniattia ta pidkhody do otsiniuvannia [Efficiency of state administration: concept and evaluation approaches]. Visnyk Natsionalnoi akademii derzhavnoho uprav- linnia pry Prezydentovi Ukrainy - Bulletin of the National Academy of Public Administration under the President of Ukraine, 2, 30-37 [in Ukrainian].

2. Pospielova T. V. (2011). Mekhanizmy derzhavnoho upravlinnia liudskym rozoytkom v Ukraini: monohrafiia [People Development Mechanisms in Public Administration in Ukraine: monograph]. Donetsk: Nord-Pres [in Ukrainian].

3. Bizo L., Ibrahimova I., Kikot O., Baran Ye., Fedoriv T. (2012). Rozvytok liderstva [Leadership Development]. Proekt: "Reforma upravlinnia personalom na derzhavnii sluzhbi v Ukraini” Project "HR Public Administration Reform in Ukraine”. I. Ibrahimova (Ed.) [in Ukrainian]. 